\title{
CAN WE AFFORD TO NEGLECT FOREST INSECT OUTBREAKS
}

$\prod$

$\mathrm{HE}$ June issue of the Forestry Chronicle contains an interesting and informative article on recent advances in forestry practice in Canada, by $\mathrm{Mr}$. Angus Graham. In the two or three last paragraphs of this article, there appear certain sweeping statements which, to my mind, greatly detract from an otherwise very creditable contribution. I refer, among other things, to the "laissez faire" policy which Mr. Graham seems to champion in dealing with insect outbreaks. He argues that nature itself will largely take care of any situation that may arise. Such a philosophy' is as far from representing either the truth or the mind of the informed Canadian forester, as it is from being a sign of progress. As a matter of fact, from personal acquaintance with the author, I am convinced that, in this particular part of his able dissertation, he fails to do justice to himself and that his remarks should be taken as those of a nodding Homer rather than criticized too severely.

Far be it from me to deny that there is in Nature a tendency towards a state of equilibrium. In the great biotic community which we call the Forest, all organisms, plant or animal, have their rightful place and function, but the so-called Natural Balance resulting from their interaction is, at all times very delicately poised. It is by no means static and is always even under the most ideal conditions such as existed in the ancient forest, in a state of greater or lesser oscillation. Even there, the amplitude of the disturbance must, sometimes, have been such as to present all the characteristics of a catastrophe. Yet, to all appearances, the fundamental economy of nature was not affected thereby to any notable extent. In by-gone ages, species afterspecies have in this way been wiped out of existence, but the great flow of life on this planet has not been stemmed to any appreciable extent. Some day, even the entire human family may become extinct without serious consequences except, of course, to man himself. The extraordinary direction of man's development constitutes in itself something resembling a major disturbance in the sphere of living beings. In all such matters then, "taking a really long view" is not the solution of our problems. We must, of necessity, maintain a clear-cut distinction between the economy of nature and the economy of man, if we wish to serve the best interests of our race. In other words, we must attempt to bring the operation of natural forces into harmony with the requirements of our own economy in order to safeguard not only our civilization but, perhaps, our very existence. This is tantamount to saying that, unless properly used, man's highest, natural endowment, his 
intelligence, is apt to become the prime cause of his own un-doing. This applies generally to all lines of human endeavour, forestry not excepted.

In recent times, particularly, the demands of civilization upon the natural resources of the world have increased somewhat after the manner of a geometric progression. Nature will not be able to meet these ever growing requirements indefinitely, unless man himself is able to make the necessary re-adjustments. He is ever confronted with a double problem, that of natural disturbances on the one hand and that of man-made disturbances on the other, the latter probably being the more far-reaching and more frequent of the two. All insect outbreaks fall into the one or the other of these categories. To expect that the great Balance of nature will act as a nostrum in every case and to dismiss all outbreaks indiscriminately on such grounds, amounts to adopting tactics which popular fancy ascribes to the ostrich and is a procedure not worthy of beings endowed with the power of reason.

Now, what does Mr. Graham contend? I quote verbatim from page 131: "In fact, these attacks of budworm, spruce sawfly, or hemlock looper are really no more than natural substitute for the fellings that should have been made in the over-mature stands, and as such need not be regarded as likely to have permanently disastrous effects."

It would, indeed, be difficult to produce a more inaccurate- statement than the above. Insects do not distinguish between trees on the basis of human economics. They take everything that is palatable to them whether it be valuable to man or simply "de trop." Perhaps, in pre-historic times insects were, to use Mr. Graham's own words, "the natural substitutes" for the modern forester and, probably they did a good job. Things are very different now. Little or nothing of the old virgin forest is left and what there is of it is contiguous with or dangerously close to areas which have been profoundly affected by the inroads of civilized man. The forester has become indispensable. If, however, this much needed forester is concerned only with roadbuilding, logging operations for immediate profit and some system or other of fire protection, and cares little or nothing about the forest as an ecological unit, he will make a very poor showing in comparison with the insect of the forest primeval. Actions speak louder than words and the recent record of the Dominion and provincial forestry services as well as that of the most important industrial organizations is very far from being one of indifference and in action in the matter of insect control.

In some instances, over-maturity of trees may have a causal relation to insect outbreaks, but in none of the cases cited by Mr. Graham does it act as such. With the spruce budworm over-maturity is an important contributory factor to the total amount of damage entailed, but that it plays any part in the rise of an infestation is by no means certain. In the majority of spruce bud- 
CAN WE AFFORD TO NEGLECT INSECT OUTBREAKS 79

worm epidemics, ill-planned and wasteful logging operations, resulting in the development of extensive areas of pure balsam stands had as much to do with this as anything else.

Neither the European spruce sawfly nor the hemlock looper show the slightest sign of respect for the old age or the youth of trees. If Mr. Graham had chosen bark-beetles, instead of the above mentioned species, his argument might have had at least, a semblance of validity.

Furthermore, the spruce budworm and the hemlock looper have for ages been part and parcel of the biotic community of the Canadian forest, the European spruce sawfly is a stow-away of modern commerce. By what sort of logic can one justify our indiscriminate acceptance of these three as "natural substitutes" for fellings that should have been made? Moreover, is it more apt to refer to insects as "natural substitutes" for this or that man-made forest operation than to speak of my own good teeth as "natural substitutes" for a false set? Certainly, in making out a good case in defence of Canadian forestry, it should have been not only profitable but comparatively easy to investigate recent trends, advances and actual accomplishments in the field of Forest Entomology. I am writing this brief reply merely because I believe that misrepresentations, unintentional though they may be, should be rectified, if for no other reason than to prevent their becoming a part of a type of "propaganda" wors: than that specifically mentioned and deprecated by Mr. Graham in his article.

August 24, 1935.

J. J. DEGRYSE, Acting Chief, Division of Forest Insects. 
The Editor wishes to acknowledge the courtesy of Mr. Koroleff, Secretary-Forester of the Woodlands Section of the Canadian Pulp and Paper Association in permitting him to use the article "The Present Position of Forest Management, Protection and Silviculture in Canada" by Angus Graham, in the June number.

INDEX TO ADVERTISERS

Bartlett Manufacturing Co.

Bedard, Odilon.

Canadian Airways, Ltd.

DeHurst Forest Seed.

Dominion Skyways, Ltd.

Forest Services.

Grand'Mère Knitting Co., Ltd.

Hughes Owens, Co., Ltd.

Northern Electric Co., Ltd.

Peterborough Canoe Co., Ltd.

Quebec Forest School.

New Brunswick University.

Watson Jack \& Co., Ltd.

Woods Manufacturing Co., Ltd.

\section{The Quebec Forestry School QUEBEC CITY}

It is affiliated with Laval University and subsidized by the Government. The course's clurition is three years. Baclelors of Arts and Sciences are admitted without an duration is thre years. Bache to pass a University examination on letters and sciences. Theory is supplemented by practicil work in a forest close to Quebec. Every year free tuition is given to five students after a special elimination contest.

Students are employed cluring the vacation either by Government or private con-

AVILA BEDARD, Dean 